\title{
The Possible Role of the Cytosolic Domain of Heparan Sulfate Proteoglycan, Syndecan
}

\author{
膜貫通型ヘパラン硫酸プロテオグリカン、シンデカンの細胞質ドメインの役割
}

Key Words :signal transduction, syndecan, transmembrane-type heparan sulfate proteoglycan

The sugar moiety of proteoglycans on the cell surface has been considered to function as i) a coreceptor for growth factors or cytokines, facilitating ligand binding to their high affinity receptors and fixing ligands in the pericellular space and ii) an important molecular regulator of cell adhesion. Recently, several papers reported that the cytosolic regions of core proteins of transmembrane type heparan sulfate proteoglycans, the syndecan family, may function in the signal transduction. The cytosolic residues of the syndecan family are phosphorylated by variouscell treatments, for example phosphorylations of Tyr in the cytosolic region of core protein of syndecan-1, Ser in syndecan-2, Ser and Tyr in syndecan-3, and Ser in syndecan-4, and PKC was activated by the syndecan- 4 binding to PKC [Reiland, J. et al. (1996) Biochem. J. 319, 39-47; Itano, N. et al. (1996) Biochem. J. 315, 925-930; Prasthofer, T. et al. (1995) Biochem. Mol. Biol. Int. 36, 793-802; Asundi, V. K. and Carey D. J. (1997) Biochem. Biophys. Res. Commun. 240, 502-506; Oh, E. S.et al. (1997) J. Biol. Chem. 272, 8133-8136; Horowitz, A. and Simon, M. (1998) J. Biol. Chem. 273, 10914-10918].

Here I would like to briefly summarize a paper, "Cortactin-Src kinase signaling pathway is involved in Nsyndecan-dependent neurite outgrowth" [Kinnunen, T. et al. (1998) J. Biol. Chem. 273, 10702-10708]. This paper reports that the cytosolic domain of N-syndecan (syndecan-3, one of the syndecan family) interacts with the intracellular proteins, cortactin and Src tyrosine kinase, and may function in the signal transduction triggered by HB-GAM (heparin binding growthassociated molecule) to induce neurite formation. HB-GAM is an extracellular matrix associated protein expressed in the developing neural tissue, and has the neurite outgrowth-promoting activity, the mitogenic activity, and the transforming activity to various types of cells. $\mathrm{N}$-syndecan is localized on the surface of neurites and the growth cones of neurites of neurons cultured on HB-GAM-coated matrix in vitro. $\mathrm{N}$-syndecan is spatiotemporally co-expressed with HB-GAM in the developing rat brain. Since N-syndecan could be isolated using HB-GAMimmobilized column from the detergent extract of the perinatal rat brain, it has been suggested that $\mathrm{N}$-syndecan acts as a receptor for HB-GAM and mediates the neurite growth-promoting signal of HB-GAM for the formation of cytoskeleton of neurites. The authors reported the study into the signal transduction of HB-GAM mediated by N-syndecan. N18 neuroblas-
細胞表面に存在するプロテオグリカンは、これまで主にそ の糖部分の働きに光が当てられてきた。すなわち、その硫酸化 グリコサミノグリカンと他分子の結合を通じてi 細胞増殖因子 やサイトカインが高親和性レセプターへ結合するのを容易にし たり、細胞表面にそれら因子を留めたりする低親和性レセプ ターとして、ii) 細胞接着を制御する重要な分子として機能する と考えられている。これに加えて、最近、細胞膜貫通型へパラ ン硫酸プロテオグリカンであるシンデカンファミリーに関して、 そのコアプロテインの細胞内領域が細胞内シグナル伝達に関与 する可能性が指摘されてきている。具体的には、シンデカン -1 のコアプロテインの細胞内領域のチロシン、シンデカン -2 のセ リン、シンデカン -3 のセリン、チロシン、シンデカン -4 のセリ ンがリン酸化を受けること、そしてシンデカン -4 が PKC と直 接結合し、PKC を活性化できることなどが報告されている [Reiland, J. et al. (1996) Biochem. J. 319, 39-47; Itano, N. et al. (1996) Biochem. J. 315, 925-930; Prasthofer, T. et al.(1995) Biochem. Mol. Biol. Int. 36, 793-802; Asundi, V. K. and Carey, D.J. (1997) Biochem. Biophys. Res. Commun. 240, 502-506; Oh, E. S. et al.(1997) J. Biol. Chem. 272, 8133-8136; Horowitz, A. and Simon, M. (1998) J.Biol. Chem. 273, 10914-10918]。

ここで紹介する論文 “Cortactin-Src kinase signaling pathway is involved in $\mathrm{N}$-syndecan-dependent neurite outgrowth" [Kinnunen, T. et al. (1998) J. Biol.Chem. 273, 10702-10708]は、シ ンデカンファミリーの一つである N- シンデカン (N-syndecan、 別名 syndecan-3) が HB-GAM (heparin binding growth-associated molecule) からのシグナル伝達に関与し、そのシグナルには細胞 内の cortactin と Srcチロシンキナーゼが関わっていることを示 唆したものある。HB-GAM は、発達段階の神経組織に強く発現 する細胞外マトリクス結合タンパク質で、神経突起伸長促進活 性、種々の細胞に対する分裂促進活性、形質転換活性を有する 分子である。N-シンデカンは、in vitro で HB-GAM をコートし たマトリクス上でのニューロンの神経突起表面と神経成長円錐 に局在し、またin vivoにおいても、脳の発達段階において、時 間的空間的に HB-GAM との共発現がみられる。さらにN-シン デカンが出生前後のラット脳の抽出液から HB-GAM 結合タン パク質として単離されたことから、N-シンデカンは HB-GAM のレセプターとして作用し、神経突起伸長促進のシグナルを神 経突起の細胞骨格へ仲介することが示唆されていた。著者らは、 N-シンデカンによって仲介される HB-GAM からの細胞内への シグナルについて研究をすすめた。ラット N-シンデカンの cDNA をトランスフェクトした N18 神経芽細胞腫では、HB- 
toma cells transfected with a rat $\mathrm{N}$-syndecan expression vector showed the enhancement of HB-GAM-dependent neurite growth. The tyrosine kinase inhibitor, herbimycin $\mathrm{A}$, and $\mathrm{Src}$ family kinase-specific inhibitor, PP1, inhibited N-syndecan-dependent neurite outgrowth. The localization of $\mathrm{N}$-syndecan in the transfectant was detected in the cell body and neurites, especially in the growth cone and filopodia by immunofluorescence staining.

To isolate proteins interacting with the cytosolic domain of $\mathrm{N}$-syndecan, the crude extracts of rat brain were applied to the column containing immobilized synthetic peptide of the cytosolic region of $\mathrm{N}$-syndecan. The binding proteins were eluted with the same peptide used as the affinity matrix. The eluted fraction was incubated with $\left[\gamma-{ }^{32} \mathrm{P}\right]-\mathrm{ATP}$ and subjected to SDS-PAGE and autoradiography. A phosphorylated protein at a molecular weight of $80 \mathrm{kDa}$ was detected, indicating that a kinase activity, together with a substrate, bound specifically to the cytosolic moiety of $\mathrm{N}$-syndecan attached to the column. The results of the immunoprecipitation and the western blot confirmed that the peptide eluted fraction contained c-Src, Fyn, cortactin (the substrate for $\mathrm{c}-\mathrm{Src}$ ), tubulin, and a $30 \mathrm{kDa}$ protein. The effect of $\mathrm{N}$-syndecan and HB-GAM on phosphorylation of Src kinases and their substrates was examined further. Nsyndecan transfectants grown on HB-GAM matrix exhibited an increased level of the phosphorylation of c-Src and cortactin, while mock transfectants showed only a slight change. On the basis of these results, the authors suggested that $\mathrm{N}$-syndecan bound to the protein complex containing Src family tyrosine kinase and their substrates, and acted as a neurite outgrowth receptor via Src kinase-cortactin pathway.

What triggers this signaling? It would be 1) the dimerization or multimerization of receptors as is the case of the receptor type protein tyrosine kinase or 2) the structural change of the cytosolic domain of syndecan produced by the binding of ligand. The same authors reported that HB-GAM bound to heparan sulfate chain of $\mathrm{N}$-syndecan [Kinnunen, T. et al. (1996) J. Biol. Chem. 271, 2243-2248]. Therefore, it is still an unsolved question how the binding of HB-GAM to Nsyndecans links to the signaling via the cytosolic domain of $\mathrm{N}$ syndecan to other cytosolic proteins.

As described above, there are reports that the serine and the tyrosine residues in the cytopalsmic domains of the syndecan family can be phosphorylated in cultured cells. Considering these results, the function of the phosporylation of the cytosolic domain of $\mathrm{N}$-syndecan needs to undergo further studies in terms of the signal transduction of HB-GAM for the neurite formation, and another question is whether the interaction of the cytosolic domain of N-syndecan with c-Src and its substrate is specific to N-syndecan or not.

Recently, the interactions of two proteins involved in the organization of the cytoskeleton and the signaling with the
GAM 依存的な神経突起伸長の元進が認められた。この N-シン デカン依存的神経突起伸長はチロシンキナーゼ阻害剤 herbimycin A と Src family kinase の特異的な阻害剤 PP1によっ て阻害された。トランスフェクタントにおけるN-シンデカン は、蛍光抗体法により細胞体と神経突起、とくに神経成長円錐 および糸状仮足に検出された。

さらに著者らは、N-シンデカンの細胞内ドメインと結合す るタンパク質を単離する目的で、ラット脳の粗抽出液を $\mathrm{N}$-シン デカンの全細胞内領域に相当する合成ペプチドを固定化したカ ラムにかけ、固定化に使用したのと同じ合成ぺプチドによって 溶出した。この溶出画分に $\left[\gamma-{ }^{32} \mathrm{P}\right]-\mathrm{ATP}$ を加えて反応させた後、 電気泳動にかけ、オートラジオグラフィーで調ベたところ、80 $\mathrm{kDa}$ のリン酸化タンパク質が検出され、キナーゼ活性およびそ の基質が特異的にN-シンデカンの細胞内ドメインと結合するこ とが示された。さらに、免疫沈降やウエスタンブロットにより、 そのキナーゼ活性を有する画分にc-Src、Fyn、c-Src の基質とし て知られる cortactin、そして tubulin および未知の $30 \mathrm{kDa}$ タン パク質が同定された。Src と cortactinのリン酸化に対するN-シ ンデカンと HB-GAM の結合の影響を調べたところ、HB-GAM 上のN-シンデカントランスフェクタントでは c-Src と cortactin のリン酸化の六進が見られたが、Mockトランスフェクタントで はわずかな変化しか認められなかった。こうして、著者らはNシンデカンが Src ファミリーチロシンキナーゼとその基質を含 むタンパク質複合体に結合し、N-シンデカンが Src kinasecortactin 経路を介して神経突起伸長に働くレセプターとして作 用することを示唆している。

このシグナルが on になる状況についてはいくつかの可能 性が考えられる。例えば、レセプター型のプロテインチロシン キナーゼで知られているようなレセプターの 2 量体化、あるい は多量体化が必要である、あるいはシンデカンのコアプロテイ ンの構造がリガンドの結合によって変化し、その変化が細胞内 ドメインに伝わって生じるといった可能性である。HB-GAM は N-シンデカンのヘパラン硫酸鎖を介して結合することが、同じ 著者らによって報告されている[Kinnunen, T. et al. (1996) J. Biol. Chem. 271, 2243-2248]。HB-GAM のN-シンデカンの糖鎖への結 合が、いかにしてN-シンデカンの細胞内ドメインを介したシグ ナリングに結びつくのか、非常に興味深い。

最初に述べたように、シンデカンファミリー分子で細胞内 領域のセリンやチロシンのリン酸化が報告されていることから、 この現象においてN-シンデカンそのものの細胞内領域のリン酸 化がどうなっているかも興味あるところである。シンデカンの 細胞内領域とシグナル伝達関連分子との結合が $\mathrm{N}$-シンデカンに 特異的なのか、他のシンデカンでも同様の現象があった場合、 そこに関わる分子はやはり Src-cortactin 経路であるのかも知り たいところである。

また、最近、yeast の two hybrid system を用いて、細胞骨 格形成、シグナリングに関わる分子がシンデカン -2 の細胞内領 
cytosolic region of syndecan- 2 were found by the yeast two hybrid system. These two are syntenin [Grootjans, J. J. et al. (1997) Proc. Natl. Acad. Sci. USA 94, 13683-13688] and CASK/LIN-2 [Hsueh, Y-P. et al. (1998) J. Cell Biol. 142, 139151]. Syntenin is a protein containing PDZ domain, which is coined with the first letters of PSD-95, Dlg, and ZO-1. CASK/ LIN-2 is a protein containing PDZ and SH3 domains. Syntenin could also bind to syndecan- 1 and -4 and CASK/LIN-2 to syndecan-1. A deletion or substitution experiment around Cterminal FYA sequence of syndecan-2, which is conserved among the syndecan family, suggested the possibility that all syndecans can bind to PDZ domain of syntenin or CASK/LIN2. It was reported that CASK/LIN-2 also binds to protein 4.1, the actin binding protein, [Cohen, A. R. et al. (1998) J. Cell Biol. 142, 139-151], suggesting that syndecan links to the cytoskeleton via CASK/LIN-2 and protein 4.1.

The results of the yeast two hybrid system of these two papers and $\mathrm{N}$-syndecan-affinity chromatography suggest that a signal, for example HB-GAM, is transmitted to the cytoskeleton rearrangement through the formation of a complex with $\mathrm{Src}$, cortactin and the cytosolic region of $\mathrm{N}$-syndecan via PDZ domain and the interaction of these components. Several factors have emerged from these works and the number of factors participating in this signal transduction will increase further. The elucidation of the molecular mechanism of the interaction of these factors through signal transduction is becoming more fascinating.

\section{Reported by Yoneda, A.}

Biosignaling Department, National Institute of Bioscience and Human-Technology

Agency of Industrial Science and Technology

Tsukuba, Ibaraki, 305-8566, Japan

FAX: 81-298-54-6095
域と相互作用することが見出された。それらは、シンテニン (syntenin) と名付けられた PDZ ドメイン (PSD-95, Dlg, ZO-1に 共通のドメインであり、これらの頭文字をとって名付けられ た。）をもつ新規タンパク質 [Grootjans, J. J. et al. (1997) Proc. Natl. Acad. Sci. USA 94, 13683-13688] と、PDZ 及び SH3 ドメインを もつ CASK/LIN-2 [Hsueh, Y-P. et al. (1998) J. Cell Biol. 142, 139151]である。シンデカン-2 に加えて、シンテニンはシンデカン1、-4 とも、CASK/LIN-2 はシンデカン -1 とも結合できること が示されている。この 2 種類の分子とシンデカンの結合は、シ ンデカンファミリー間で保存されているC末端の FYA 配列を介 しているため、この結合はシンデカンファミリーで共通してあ り得ることが示唆されている。さらに、CASK/LIN-2 は protein 4.1 という actin 結合タンパク質とも結合することが示されてお り [Cohen, A. R. et al. (1998) J. Cell Biol. 142, 129-138]、これに よってシンデカンが細胞骨格と CASK/LIN-2 および protein 4.1 を介して連結していることが示唆されている。

この 2 つの論文での two hybrid system の結果と、先の Nシンデカンの細胞内領域のアフィニティークロマトグラフィー の結果を併せて考えると、Src および cortactin は、PDZドメイ ンをもつタンパク質を含む複合体に存在し、その複合体が PDZ ドメインを介してN-シンデカンの細胞内領域に結合する可能性 も考えられる。このように、シンデカンのコアプロテイン自身 のシグナル伝達や細胞骨格の構築への関与について、そこに関 わるいろいろな役者が顔をそろえだしはじめており、今後は、 細胞の外と内のつながりなど、分子メカニズムの解明が楽しみ である。

工業技術院 生命工学工業技術研究所 生体情報部 今村 亨 グループ

米田 敦子 